\title{
CINEMA, DEMOCRACY \\ AND PERFECTIONISM
}

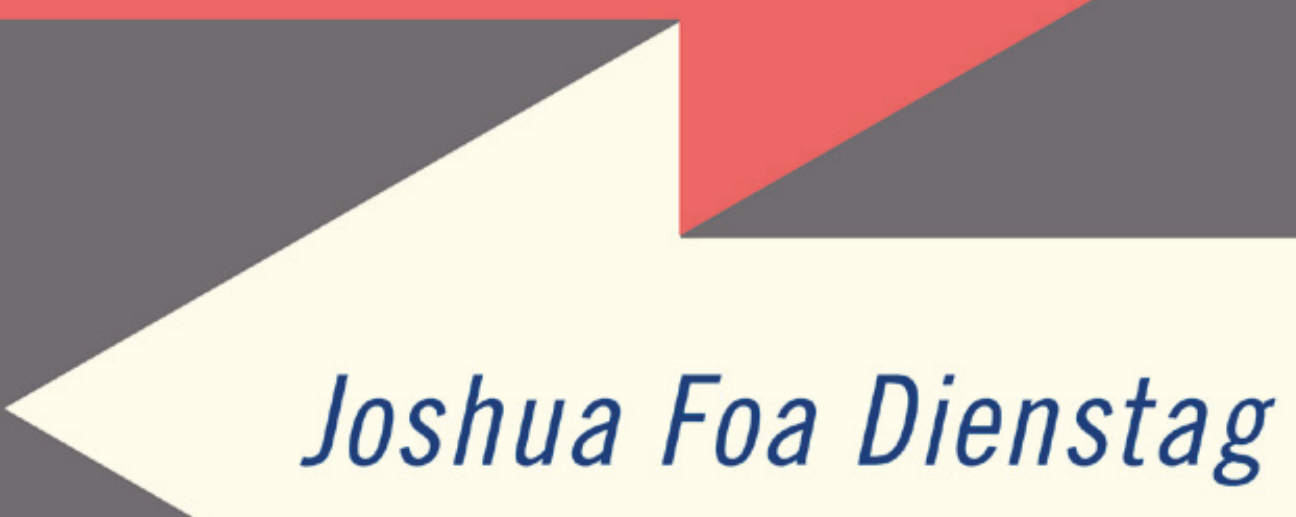

\section{IN DIALOGUE}

CRITICAL POWERS SERIES 


\section{Cinema, democracy and perfectionism}

\section{MANCHESTER 1824}

Manchester University Press 


\title{
CRITICAL POWERS
}

\author{
Series Editors: \\ Bert van den Brink (University of Utrecht), \\ Antony Simon Laden (University of Illinois, Chicago), \\ Peter Niesen (University of Hamburg) and \\ David Owen (University of Southampton).
}

Critical Powers is dedicated to constructing dialogues around innovative and original work in social and political theory. The ambition of the series is to be pluralist in welcoming work from different philosophical traditions and theoretical orientations, ranging from abstract conceptual argument to concrete policy-relevant engagements, and encouraging dialogue across the diverse approaches that populate the field of social and political theory. All the volumes in the series are structured as dialogues in which a lead essay is greeted with a series of responses before a reply by the lead essayist. Such dialogues spark debate, foster understanding, encourage innovation and perform the drama of thought in a way that engages a wide audience of scholars and students.

\section{Published by Bloomsbury}

On Global Citizenship, James Tully

Justice, Democracy and the Right to Justification, Rainer Forst

\section{Forthcoming from Manchester University Press}

Rogue Theodicy - Politics and power in the shadow of justice, Glen Newey

Democratic Inclusion, Rainer Baubock

Law and Violence, Christoph Menke Autonomy Gaps, Joel Anderson

Toleration, Liberty and the Right to Justification, Rainer Forst 


\title{
Cinema, democracy and perfectionism
}

\author{
Joshua Foa Dienstag in dialogue
}

Edited by Joshua Foa Dienstag

Manchester University Press 
While copyright in the volume as a whole is vested in Manchester University Press, copyright in individual chapters belongs to their respective authors, and no chapter may be reproduced wholly or in part without the express permission in writing of both author and publisher.

\author{
Published by Manchester University Press \\ Altrincham Street, Manchester M1 7JA \\ www.manchesteruniversitypress.co.uk \\ British Library Cataloguing-in-Publication Data \\ A catalogue record for this book is available from the British Library \\ Library of Congress Cataloging-in-Publication Data applied for \\ ISBN 9781784994013 hardback \\ ISBN 9781784994020 paperback \\ ISBN 9781784997359 open access
}

First published 2016

An electronic version of this book is also available under a Creative Commons

(CC-BY-NC-ND) licence

The publisher has no responsibility for the persistence or accuracy of URLs for any external or third-party internet websites referred to in this book, and does not guarantee that any content on such websites is, or will remain, accurate or appropriate.

Typeset by Out of House Publishing 